\title{
THE IMPLEMENTATION OF GOVERNMENT ACCOUNTING STANDARDS, INTERNAL CONTROL SYSTEMS AND INFORMATION TECHNOLOGY UTILIZATION ON THE QUALITY OF LOCAL GOVERNMENT FINANCIAL STATEMENTS WITH ORGANIZATIONAL COMMITMENTS AS MODERATION VARIABLES
}

${ }^{1 *}$ Annisa Elfatikha Kharisma Adnin dan ${ }^{2}$ Suci Atiningsih

${ }^{12}$ Program Studi Akuntansi STIE BANK BPD Jateng elfatikha@gmail.com

\begin{tabular}{l} 
INFO ARTIKEL \\
Histori Artikel : \\
Tgl. Masuk : 13 Juli 2020 \\
Tgl. Diterima : 29 September 2020 \\
Tersedia Online : 29 September 2020 \\
\hline Keywords: \\
government accounting standards, \\
internal control systems, information \\
technology, local government financial \\
reports and organizational commitment
\end{tabular}
ABSTRACT

The purpose of this study to determine the effect of the application of government accounting standards, internal control systems and the use of information technology on the quality of local government financial reports with organizational commitment as a moderating variable conducted in the Regional Government Work Unit (SKPD) of the Brebes Regency Government. The population in this study was 49 SKPD of the Brebes Regency Government. Sampling using a purposive sampling technique. The sample is the head of finance, treasurer and accounting staff. This research uses primary data. Data analysis uses the SmartPLS3.0 application. The results of this study are the application of accounting standards, internal control systems and the use of information technology have a positive effect on the quality of financial statements, organizational commitment is not able to moderate the influence of the application of accounting standards and internal control systems on the quality of financial statements of local governments, but organizational commitment is able to strengthen the influence of technology use information on the quality of local government financial reports.

\section{PENDAHULUAN}

Perubahan sistem pemerintahan dari sentralistik ke desentralistik dan tuntutan masyarakat mendorong pemerintah untuk bekerja lebih baik. Perubahan tersebut merupakan rangkaian pemerintah dalam mewujudkan good governance dan clean governance.Kebijakan sistem ke desentralistik merupakan cara pemerintah untuk meningkatkan kemandirian Pemerintah Daerah melalui otonomi daerah. Dalam mewujudkan tata kelola pemerintahan yang baik dan pemerintahan yang bersih, Pemerintah Daerah terus melakukan upaya peningkatan transparansi dan akuntabilitas pengelolaan keuangan daerah denganmewajibkan setiap satuan kerja untuk mempertanggungjawabkan keuangan daerah secara transparan kepada public.

Laporan Keuangan Pemerintah Daerah (LKPD) harus mengikuti standar akuntansi pemerintah sesuai Peraturan Pemerintah No. 71 Tahun 2010.Tujuan diberlakukannya hal tersebut adalah agar laporan keuangan lebih accountable (dapat dipertanggungjawabkan)dan meningkatkan kualitas laporan keuangan. Laporan Keuangan Pemerintah Daerah 
yang berkualitas dapat dilihat dari opini Badan Pengawas Keuangan (BPK) selaku badan yang memeriksa dan menilai LKPD (Andrianto \& Rahmawati, 2017).

Pada periode 2018 BPK perwakilan Jawa Tengah telah melaksanakan audit untuk menilai kualitas laporan keuangan dengan hasil berupa grafik yang menggambarkan pertumbuhan opini LPKD. Berdasarkan data yang diperoleh Jawa Tengah telah mengalami peningkatan dalam pembuatan laporan keuangan, namun masih ada satu Pemerintah Daerah yang mendapat opini WDP yaitu Pemerintah Kabupaten Brebes. Pemerintah Kabupaten Brebes mendapat opini WDP dari BPK dari tahun 2012 hingga 2018 yang berarti bahwa masih ada hal yang salah dalam penyajian Laporan Keuangan (semarang.bpk.go.id).

Opini WDP diberikan oleh BPK dengan ketentuan bila sebagian besar informasi yang termuat dalam laporan keuangan bebas dari salah saji material, namun masih ada rekening atau item yang menjadi pengecualian, adanya ketidakwajaran dalam item tertentu namun ketidakwajaran tersebut tidak mempengaruhi kewajaran laporan keuangan secara menyeluruh. Opini WDP yang didapat Pemerintah Kabupaten Brebes disebabkan oleh beberapa faktor yang mencakup aset tetap tanah, peralatan dan mesin, gedung dan bangunan, jalan, irigasi dan jaringan , aset tetap lainnya, konstruksi dalam pengerjaan dan akumulasi (jurnaljateng.com, 2018)

Berdasarkan artikel jurnaljateng.com (2018) BPK menemukan masalah mengenai pencatatan yang salah sehingga mengakibatkan selisih antara Kartu Inventaris Barang(KIB) dengan neraca yang tidak dapat dijelaskan, kemudian penataan aset tetap pada KIB belum dilakukan secara memadai, masih terdapat aset yang tidak diyakini kewajarannya, aset yang belum tercatat dan belum diketahui nilainya dan tanah yang tidak bersertifikat. Permasalahan tersebut mengindikasikan bahwa Pemerintah Kabupaten Brebes belum menerapkan standar akuntansi pemerintah dalam penyajian laporan keuangan.Lemahnya sistem pengendalian intern mengakibatkan kesalahan dalam proses pembuatan laporan keuangan, sehingga kurangnya kepatuhan terhadap hukum dan peraturan, keandalan laporan keuangan dan data keuangan serta kegiatan yang kurang efektif dan efisien. Keterlibatan penggunaan teknologi informasi juga mempengaruhi kualitas laporan keuangan, dengan pemanfaatan teknologi informasi proses pencatatan, penyimpanannya dan melindungi pengiriman informasi secara aman.

Berdasarkan fenomena tersebut dapat diketahui bahwa Pemerintah Daerah Kabupaten Brebes masih mengalami kendala dalam penyajian laporan keuangan sehingga perlu adanya penelitian.Kualitas laporan keuangan dipengaruhi oleh beberapa faktor yang perlu diteliti dan diidentifiksi sehingga dapat menjadi bahan pertimbangan dan masukan bagi Pemerintah Kabupaten Brebes untuk meningkatkan kualitas laporan keuangan.Faktor-faktor yang dapat mempengaruhi kualitas laporan keuangan adalah penerapan standar akuntansi pemerintah, sistem pengendalian intern dan pemanfaatan teknologi informasi.

Setyaningrum \& Atiningsih (2019) menyatakan sistem pengendalian intern berpengaruh positif dan signifikan terhadap kualitas laporan keuangan Pemerintah Daerah, sedangkan Mokoginta,dkk. (2017) dimana sistem pengendalian intern berpengaruh negatif dan signifikan terhadap kualitas laporan keuangan. 
Kualitas laporan keuangan didukung dengan adanya pemanfaatan teknologi informasi dengan menggunakan aplikasi komputer akuntansi pada pengelolaan keuangan daerah. Penerapan sistem komputerisasi akuntansi pada Pemerintah Daerah akan mempercepat proses pencatatan, penyajian dan analisis laporan keuangan Pemerintah Daerah karena aplikasi komputer akuntansi diciptakan untuk mencatat transaksi-transaksi akuntansi kedalam sebuah laporan dan analisa laporan untuk mendukung pengambilan keputusan sehubungan dengan kondisi keuangan dalam satu periode akuntansi (Nadir \& Hasyim, 2017). Teknologi informasi dirancang untuk mempermudah proses pengolahan data transaksi dan penyajian laporan keuangan sehingga laporan keuangan dapat disajikan tepat waktu. Ketepatwaktuan pelaporan keuangan akan menyebabkan nilai informasi menjadi relevan dan meningkatkan kualitas laporan keuangan (Andrianto \& Rahmawati, 2017). Armel et al. (2017) \& Andrianto\& Rahmawati (2017) bahwa pemanfaatan teknologi informasi berpengaruh positif dan signifikan terhadap laporan keuangan Pemerintah Daerah, sedangkan Setyowati (2016) bahwa peran teknologi informasi tidak berpengaruh terhadap laporan keuangan.

Perbedaan hasil penelitian di atas dapat disebabkan oleh adanya faktor lain, salah satunya adalah komitmen organisasi. Pegawai Pemerintah Daerah dalam melaksanakan tugas perlu memiliki komitmen organisasi, karena komitmen organisasi akan mempertahankan kepatuhan dalam menyajikan laporan keuangan pemerintah yang berkualitas sesuai dengan standar akuntansi pemerintah. Komitmen organisasi adalah hubungan antara organisasi dan individu, dimana individu mempunyai keinginan agar tetap bertahan didalam organisasi karena memiliki keyakinan terhadap tujuan organisasi (Setyaningrum \& Atiningsih, 2019). Dengan berlakunya standar akuntansi pemerintah, diterapkannya pengendalian intern, dan pemanfaatan teknologi yang dikaitkan dengan komitmen organisasi diharapkan dapat terwujud laporan keuangan yang berkualitas sesuai dengan Peraturan Pemerintah No. 71 Tahun 2010 tentang Standar Akuntansi Pemerintah. Penelitian ini lebih menarik dari penelitian sebelumnya karena sebagian besar penelitian sebelumnya pengolahan datanya menggunakan analisis regresi berganda atau SPSS tetapi dalam penelitian ini menggunakan aplikasi SmartPLS3.0 dimana dalam SmartPLS3.0 ini mengatasi kekurangan di SPSS.

Perumusan masalah yang diangkat dalam penelitian ini adalah 1) Apakah penerapan Standar Akuntansi Pemerintah berpengaruh positif terhadap kualitas laporan keuangan Pemerintah Daerah, 2) Apakah sistem pengendalian intern berpengaruh positif terhadap kualitas laporan keuangan Pemerintah Daerah, 3) Apakah pemanfaatan teknologi informasi berpengaruh positif terhadap kualitas laporan keuangan Pemerintah Daerah, 3) Apakah pemanfaatan teknologi informasi berpengaruh positif terhadap kualitas laporan keuangan Pemerintah Daerah, 4) Apakah komitmen organisasi mampu moderasi pengaruh Penerapan Standar Akuntansi Pemerintah terhadap kualitas laporan keuangan Pemerintah Daerah, 5) Apakah komitmen organisasi mampu moderasi pengaruh sistem pengendalian intern terhadap kualitas laporan keuangan Pemerintah Daerah dan 6) Apakah komitmen organisasi mampu moderasi pengaruh pemanfaatan teknologi informasi terhadap kualitas laporan keuangan Pemerintah Daerah.

KERANGKA TEORITIS DAN PENGEMBANGAN HIPOTESIS 
Kualitas Laporan Keuangan Pemerintah Daerah

Laporan keuangan merupakan laporan yang terstruktur mengenai posisi keuangan dan transaksi-transaksi yang dilakukan oleh suatu entitas dengan tujuan menyediakan informasi mengenai posisi keuangan, realisasi anggaran, saldo anggaran lebih, arus kas, hasil operasi dan perubahan ekuitas suatu entitas pelaporan yang bermanfaat bagi para pengguna dalam membuat dan mengevaluasi keputusan mengenai alokasi sumber daya (Peraturan Pemerintah No. 71 Tahun 2010). Akuntabilitas keuangan dapat dilihat dari kualitas laporan keuangan Pemerintah Daerah atas pengelolaan Aggaran Pendapatan Belanja Daerah (APBD).Laporan keuangan yang berkualitas menggambarkan informasi yang aktual dan adil mengenai posisi keuangan dan kinerja ekonomi. Berdasarkan Peraturan Pemerintah No. 71 tahun 2010 untuk menilai kualitas Laporan Keuangan Pemerintah berdasarkan karakteristik kualitatif yaitu relevan, andal, dapat dibandingkan dan dapat dipahami.

\section{Penerapan Standar Akuntansi} Pemerintah

Standar akuntansi pemerintahan adalah standar yang mengatur bagaimana penyajian laporan keuangan demi meningkatkan keterbandingan laporan keuangan baik terhadap anggaran, antar periode, maupun antar entitas (Peraturan Pemerintah No. 71 Tahun 2010). Peraturan Pemerintah No 71 tahun 2010 dibuat untuk mengatur standar akuntansi pemerintah dengan tujuan sebagai acuan dalam :

a) Penyusunan standar dalam melaksanakan tugas

b) Penyusunan laporan keuangan dalam menanggulangi masalah akuntansi yang belum diatur dalam standar c) Pemeriksa dalam memberikan pendapat mengenai apakah laporan keuangan disusun sesuai dengan standar

d) Para pengguna laporan keuangan dalam menafsirkan informasi yang disajikan pada laporan keuangan yang disusun sesuai standar.

\section{Sistem Pengendalian intern}

Sistem pengendalian intern dibutuhkan untuk mencapai keandalan pelaporan keuangan dan pengamanan aset.Sistem akuntansi dapat menjadi subjek terjadinya kesalahan baik yang disengaja maupun tidak disengaja. Di sisi lain sistem pengendalian intern dibutuhkan untuk mencapai keandalan pelaporan keuangan, oleh karena itu sistem akuntansi memerlukan pengendalian intern (Mahmudi, 2016).

Komponen yang terdapat pada sistem pengendalian intern berdasarkan Peraturan Pemerintah No. 60 tahun 2008 adalah : 1) Lingkungan pengendalian; 2) Penilaian resiko; 3) Aktivitas pengendalian; 4) Informasi dan komunikasi; 5)Monitoring

\section{Pemanfaatan Teknologi Informasi}

Pemanfaatan teknologi mencakup adanya pengolahan data, pengolahan informasi, sistem manajemen dan proses kerja secara elektronik serta pemanfaatan kemajuan teknologi agar proses lebih efektif, efisien dan hemat biaya (Nadir \& Hasyim, 2017).

Peraturan Pemerintah No. 56 Tahun 2005 tentang Sistem Informasi Keuangan menyebutkan bahwa untuk menindaklanjuti pelaksanaan proses pembangunan sesuai dengan prinsipprinsip tata kelola yang baik, Pemerintah Pusat dan Pemerintah Daerah berkewajiban untuk mengembangkan dan memanfaatkan kemajuan teknologi informasi untuk meningkatkan kemampuan mengelola keuangan, dan 
mendistribusikan informasi keuangan ke layanan publik.

\section{Komitmen Organisasi}

Komitmen organisasi adalah keadaan dimana seseorang telah mengenal jauh tentang organisasinya dan adanya keterikatan seseorang dengan organisasi tempat bekerja. Seseorang yang terikat dengan organisasi memiliki keinginan untuk tetap menjadi anggota organisasi, akan menunjukan kesediaan untuk mempertahankan keanggotannya dalam organisasi dan berusaha maksimal dalam mencapai tujuan organisasi (Andrianto \& Rahmawati, 2017). Meyer dan Allen (1991) mengatakan komitmen organisasi terdiri dari tiga komponen, yaitu : 1) Komitmen afektif, 2) Komitmen berkelanjutan dan 3)Komitmen normatif. Komponen afektif merupakan komponen yang penting sehingga dibutuhkan oleh setiap organisasi. Pegawai yang memiliki loyaitas, yaitu pegawai yang memiliki komitmen afektif karena pegawai akan cenderung tetap tinggal bekerja dalam organisasi (Siwambudi et al., 2017).

\section{Pengembangan Hipotesis}

a. Pengaruh penerapan standar akuntansi pemerintah terhadap kualitas laporan keuangan Pemerintah Daerah

Penyusunan laporan keuangan yang sesuai dengan standar akuntansi pemerintah akan menghasilkan laporan keuangan yang berkualitas. Pernyataan ini didukung oleh Sanjaya \& Haryani, (2016),Sari \& Fadli, (2019)dan Armel et al. (2017) bahwa penerapan standar akuntansi berpengaruh positif dan signifikan terhadap kualitas laporan keuangan pemerintah.

$\mathrm{H}_{1}$ : Penerapan standar akuntansi pemerintah berpengaruh positif terhadap kualitas laporan keuangan Pemerintah Daerah.

Pengaruh pengendalian intern terhadap kualitas laporan keuangan Pemerintah Daerah
Pengendalian intern bertujuan untuk melindungi organisasi dari kesalahan yang disengaja maupun tidak disengaja yang dilakukan oleh manusia sehingga mengakibatkan adanya kekeliruan dan penyimpangan. Oleh karena itu sistem pengendalian intern diprediksidapat mempengaruhi penyajian laporan keuangan sesuai dengan karakteristik kualitatif laporan keuangan yang akan meningkatkan kepercayaan pada publik. Setyaningrum \& Atiningsih (2019), Sanjaya \& Haryani, (2016) dan Siwambudi et al. (2017) yang menyatakan pengendalian intern berpengaruh positif dan signifikan terhadap kualitas laporan keuangan Pemerintah Daerah.

$\mathrm{H}_{2}$ : Pengendalian intern berpengaruh positif terhadap kualitas laporan keuangan Pemerintah Daerah

b. Pengaruh

pemanfaatan teknologi informasi terhadap kualitas laporan keuangan Pemerintah Daerah

Pemanfaatan teknologi informasi mempercepat proses pengelolaan data transaksi keuangan, penyajian laporan keuangan, serta dapat menghindari kesalahan dalam melaksanakan posting dokumen buku, jurnal, buku besar hingga menjadi kesatuan laporan keuangan yang utuh sesuai dengan peraturan perundangundangan tentang pengelolaan keuangan Pemerintah Daerah. Andrianto \& Rahmawati (2017), Alminda \& Marfuah (2017) dan Adrian et al. (2019) menyatakan pemanfaatan teknologi informasi berpengaruh posotif terhadap kualitas laporan keuangan Pemerintah Daerah.

$\mathrm{H}_{3}$ : Pemanfaatan teknologi informasi berpengaruh positif terhadap kualitas laporan keuangan Pemerintah Daerah

c. Pengaruh penerapan standar akuntansi pemerintah terhadap kualitas laporan keuangan Pemerintah Daerah dengan komitmen organisasi sebagai variabel moderasi 
Standar akuntansi pemerintah merupakan standar yang telah ditetapkan oleh pemerintah dalam Peraturan Pemerintah Nomor 71 Tahun 2008 dengan tujuan agar Pemerintah Pusat dan Pemerintah Daerah dapat menghasilkan kualitas laporan keuangan yang berkualitas. Aturan ini dapat dilaksanakan apabila aparat pemerintah memiliki komitmen yang tinggi terhadap organisasinya atau instansi, sehingga dapat bekerja secara profesional, bekerja dengan giat sehingga tujuan dari organisasi dapat dicapai bersama, yaitu dengan wujud laporan keuangan yang berkualitas. Sanjaya \& Haryani, (2016) menemukan bahwa komitmen organisasi memperkuat pengaruh penerapan standar akuntansi terhadap kualitas laporan keuangan Pemerintah Daerah.

$\mathrm{H}_{4} \quad$ : Komitmen organisasi memperkuat pengaruh penerapan standar akuntansi terhadap kualitas laporan keuangan.

d. Pengaruh pengendalian intern terhadap kualitas laporan keuangan Pemerintah Daerah dengan komitmen organisasi sebagai variabel moderasi

Komitmen penting dimiliki bagi
setiap pegawai dalam menjalankan
penyelenggaraan sistem pengendalian
intern dan penyusunan laporan keuangan
yang sesuai karakteristik kualitatif.
Pegawai yang memiliki komitmen yang tinggi akan memudahkan organisasi dalam mewujudkan tujuan organisasi yang didukung dengan adanya sistem pengendalian intern. Berdasarkan kesimpulan tersebut dapat diketahui bahwa komitmen organisasi yang tinggi dapat memperkuat pengaruh sistem pengendalian intern terhadap kualitas laporan keuangan Pemerintah Daerah. Sanjaya \& Haryani, (2016), Alminda \& Marfuah (2018) dan Setyaningrum \& Atiningsih (2019) yang menyatakan komitmen organisasi memperkuat pengaruh pengendalian intern terhadap kualitas laporan keuangan Pemerintah Daerah.

$\mathrm{H}_{5} \quad$ : Komitmen organisasi memperkuat pengaruh pengendalian intern terhadap kualitas laporan keuangan.

\section{e. Pengaruh pemanfaatan} teknologi informasi terhadap kualitas laporan keuangan Pemerintah Daerah dengan komitmen organisasi sebagai variabel moderasi

Pemanfaatan teknologi informasi mempercepat proses pengelolaan data transaksi keuangan, penyajian laporan keuangan, serta dapat menghindari kesalahan dalam melaksanakan posting dokumen buku, jurnal, buku besar hingga menjadi kesatuan laporan keuangan yang utuh sesuai dengan peraturan perundangundangan tentang pengelolaan keuangan Pemerintah Daerah. Komitmen organisasi yang baik akan mempengaruhi kinerja dalam mencapai tujuan organisasi bersama, dengan meningkatkan kualitas kerja dengan pemanfaatan teknologi informasi. Alminda dan Marfuah (2018) menyatakan komitmen organisasi memperkuat pengaruh pemanfaatan teknologi informasi terhadap kualitas laporan keuangan Pemerintah Daerah. $\mathrm{H}_{6}$ : Komitmen organisasi memperkuat pengaruh pemanfaatan teknologi informasi terhadap kualitas laporan keuangan.

\section{METODOLOGI PENELITIAN}

\section{Populasi dan sampel}

Populasi dalam penelitian ini adalah Satuan Kerja Perangkat Daerah (SKPD) yang berada di Kabupaten Brebes sejumlah 49 SKPD. Pemilihan sampel dalam penelitian ini dengan menggunakan metode purposive sampling yaitu dengan teknik pengambilan sampel berdasarkan kriteria.Kriteria dalam sampel ini ialah responden yang bekerja di SKPD 
Kabupaten Brebes yang berurusan langsung dengan laporan keuangan yaitu kepala bagian keuangan, bendahara dan staf akuntansi, dengan jumlah sampelnya sebanyak 147 sampel.

\section{Definisi Operasional Data}

\section{a. Variabel dependen}

Variabel dependen dalam peneltian ini adalah kualitas laporan keuangan Pemerintah Daerah. Kualitas laporan keuangan diukur dengan kesesuaian dan kebermanfaatan untuk kebutuhan para pengguna sesuai dengan Peraturan Pemerintah No. 71 Tahun 2010 yang menjelaskan karakteristik kualitas laporan keuangan yaitu : 1) relevan, 2) andal, 3) dapat dipahami dan 4) dapat dibandingkan. (Andrianto \& Rahmawati, 2017).

b. Variabel independen

Penerapan standar akuntansi

pemerintah. SAP diukur dengan menggunakan indikator : 1) PSAP No. 01 tentang Penyajian Laporan Keuangan, 2) PSAP No. 02 tentang Laporan Realisasi Anggran berbasis Kas, 3) PSAP No. 03 tentang Laporan Arus Kas, 4) PSAP No. 04 tentang Catatan atas Laporan Keuangan, 5) PSAP No. 05 tentang Akuntansi Persediaan, 6) PSAP No. 06 tentang Akuntansi Investasi, 7) PSAP No. 07 tentang Akuntansi Aset Tetap, 8) PSAP No. 08 tentang Akuntansi Konstruksi dalam Pengerjaan, 9) PSAP No. 09 tentang Akuntansi Kewajiban, 10) PSAP No. 10 tentang Koreksi Kesalahan, 11) PSAP No. 11 tentang Laporan Keuangan Konsolidasian dan 12) PSAP No. 12 tentang Laporan Operasional(Sari \& Fadli, 2019).

\section{Sistem pengendalian intern}

Pengendalian intern telah diatur dalam Peraturan Pemerintah No. 60 Tahun 2008 mendefinisikan bahwa sistem pengendalian intern adalah proses yang yang integral pada tindakan dan kegiatan yang dilakukan secara terus menerus oleh pimpinan dan seluruh karyawan untuk memberikan keyakinan atas tercapainya tujuan organisasi melalui kegiatan yang efektif dan efisien, keandalan pelaporan keuangan, pengamanan aset Negara dan ketaatan terhadap peraturan perundangundangan. Indikator sistem pengendalian intern yaitu : 1) lingkungan pengendalian, 2) penilaian resiko, 3) kegiatan pengendalian, 4) sistem informasi dan komunikasi dan 5) pemantauan Setyaningrum \& Atiningsih, 2019).

\section{Pemanfaatan teknologi informasi}

Pemanfaatan teknologi dan informasi adalah sikap akuntan dalam menggunakan teknologi informasi untuk menyelesaikan tugas dan meningkatkan kinerja. Andrianto \& Rahmawati (2017) berpendapat indikator variabel pemanfaatan teknologi informasi dilihat dari penggunaan komputer dan jaringan yang sesuai dengan peraturan perundangundangan.

\section{c. Variabel moderasi}

Variabel moderasi dalam penelitian ini adalah komitmen organisasi, Komitmen organisasi adalah kemampuan dan kemauan dalam menyelaraskan prioritas tujuan untuk mencapai target organisasi.Indikator dalam komitmen organisasi menurut Andrianto \& Rahmawati (2017) ialah komponen afektif, komponen normatif dan komponen berkelanjutan.

\section{Metode Pengumpulan Data}

Pengumpulan data dilakukan dengan membuat kuesioner yang berisi daftar pertanyaan yang akan dibagikan ke responden untuk diisi. Pertanyaan dan pilihan jawaban dalam kuesioner dibuat berdasarkan variabel-variabel yang diukur. Kuesioner akan diberikan langsung oleh responden, kuesioner akan dikembalikan dalam jangka waktu paling lambat 1 (satu) minggu setelah penyerahan.Pengukuran menggunakan skala likert dengan skor 1 sampai 5 


\section{Metode Analisis Data}

Metode analisis data pada penelitian ini menggunakan pendekatan Partial Least Square (PLS). PLS adalah model persaman Struktural Equation Modelling (SEM) yang berbasis komponen atau varian. Penelitian ini didukung dengan aplikasi SmartPLS3. Salah satu kelebihan aplikasi SmartPLS3 yaitu mampu menguji hubungan variabel pemoderasi yang bersifat langsung, sehingga aplikasi ini sesuai dengan penelitian ini.Analisis PLSSEM terdiri dari 2 (dua) sub model yaitu model pengukuran atau outer model dan model struktural atau inner model (Ghozali \& Latan, 2015).

\section{Analisis model pengukuran (outer model)}

Model pengukuran dilakukan untuk menguji kelayakan (reliabilitas dan validitas) item atau indikator yang membentuk konstruk. Outer model dapat dilihat dari:

1) Uji Validitas

Uji validitas digunakan untuk mengetahui kualitas data dalam suatu daftar pertanyaan dalam mengidentifikasikan suatu variabel dan mengukur tingkat akurasi indikator atau dimensi melalui pengkuran besarnya korelasi antara konstruk dengan variabel latennya. Uji validitas terdiri dari 2 (dua) uji yaitu convergent validity dan discriminant validity. Convergent validity dapat dilihat dari nilaiaverage variance extracted (AVE) dan factor loading atau outer loading sedangkan discriminant validity diukur dari nilai cross loading. Data dikatakan valid apabila nilai dari factor loading $>0.7$ dengan konstruk yang diukur, namun pada penelitian tahap awal dari pengembangan skala pengukuran, nilai factor loading 0,5 0,6 masih dianggap cukup. Selain itu uji validitas data diukur berdasarkan nilai dari average variance extracted (AVE) yang harus memiliki nilai $<0.5$ dan cross loading $>0.7$ dalam satu variabel (Ghozali \& Latan, 2015).

2) Uji Reliabilitas

Uji reliabilitas dilakukan untuk membuktikan akurasi, konsistensi dan ketepatan instrument dalam mengukur konstruk secara berurutan.Uji reliabilitas dalam PLS menggunakan nilai Cronchbach alpha (CA) dan Composite reliability (CR).Composite reliability merupakan teknik statistika untuk uji reliabilitas yang mengukur nilai reliabilitas sesungguhnya dari suatu variabel.Nilai batas untuk CA dan CR adalah 0,70 (Ghozali \& Latan, 2015).

Analisis model struktural (inner model) Analisis inner outer dapat dinilai dari beberapa indikator yaitu (Ghozali \&Latan, 2015):

1) Koefisien Determinasi $\left(R^{2}\right)$

Uji koefisien $\mathrm{R}^{2}$ digunakan untuk melihat kemampuan model atau kemampuan variabel independen dalam menjelaskan variansi data pada variabel dependen. Nilai $R^{2}$ sebesar $0.70,0.45$ dan 0.25 mengindikasikan bahwa model "Kuat", "Moderat" atau "Lemah".

2) Uji Signifikansi (Uji Hipotesis)

Uji signifikansi bertujuan untuk mengetahui pengaruh antara variabel. Pengujian signifikansi atau uji hipotesis dilakukan dengan melihat nilai $p$-value dan t-statistik dengan nilai pembatas p-value < 0,05 dan t-statistik > 1,96 yang dilakukan dengan metode bootstrapping.Uji signifikansi juga dapat melihat arah dari hubungan antar variabel dengan melihat nilai original sampel.Penggunaan metode bootstrapping karena metode ini menghasilkan resampling terbaik.

\section{HASIL DAN PEMBAHASAN Deskripsi Data Penelitian}

Teknik pengambilan sampel dengan menggunakan teknik purposive sampling, yaitu teknik pengambilan sampel berdasarkan jumlah kuesioner yang kembali dan memenuhi kriteria tertentu dengan pertimbangan (Siwambudi et al., 2017).

Tingkat pengembalian kuesioner menunjukan bahwa data kuesioner yang disebar sebanyak 147 orang (100\%), kuesioner yang tidak kembali 13 (9\%), adapun kuesioner yang rusak dikarenakan tidak memenuhi kriteria sebanyak 5 (3\%) 
sehingga total data sampel yang digunakan ada 129 sampel dengan presentase $88 \%$ dari $100 \%$.

\section{Karakteristik Responden}

Data responden sebanyak 71 orang atau $55 \%$ responden berjenis kelamin pria dan 58 orang atau $45 \%$ responden adalah wanita. Jumlah responden didominasi oleh berjenis kelamin pria, dari 129 responden berdasarkan karakteristik usia diketahui responden yang berusia 25-35 tahun sejumlah 35 orang atau $27 \%$, usia $36-45$ tahun sejumlah 42 orang atau $33 \%$ dan respoden yang berusia lebih dari 45 tahun sejumlah 52 orang atau $40 \%$ dengan demikian usia pegawai tergolong usia menengah. Berdasarkan pendidikan terakhir responden dari 129 responden diketahui yang berpendidikan SMA sebanya 8 orang atau $6 \%$, D3 sebanyak 12 orang atau $9 \%$, S1 sebanyak 98 orang atau $77 \%$, S2 sebanyak 8 orang atau $6 \%$ dan slainnya 3 orang atau $2 \%$. dengan demikian tingkat pendidikan terbanyak dari pegawai yang berpendidikan tinggi. Pada tabel diketahui bahwa pegawai terbanyak telah bekerja lebih dari 10 tahun sebanyak 60 orang atau $46 \%$ dari total keseluruhan responden.

\section{Statistik Deskriptif Variabel}

Penerapan standar akuntansi pemerintah nilai minimum adalah 99,75, nilai maksimum 104,25 dan nilai rata-rata indeks indikator 103,2 (Tinggi). Menandakan bahwa rata-rata responden atau pegawai yang bekerja di SKPD Kabupaten Brebes telah melaksanakan penerapan standar akuntansi pemerintah dengan baik dalam penyusunan laporan keuangan Pemerintah Daerah. Sistem pengendalian intern memiliki nilai skor indeks terendah 97,25 , nilai skor indeks maksimum 105 dengan skor rata-rata 101,72 yang tergolong tinggi, menandakan bahwa sistem pengendalian intern dalam SKPD di Kabupaten Brebes sudah baik berdasarkan persepsi penyusunan laporan keuangan Pemerintah Daerah.

Pemanfaatan teknologi informasi bahwa nilai rata-rata indeks berada dinilai 110 yang tergolong tinggi berarti bahwa ratarata SKPD di Kabupaten Brebes telah mengoptimalkan teknologi informasi dalam proses penyusunan laporan keuangan Pemerintah Daerah. Komitmen organisasi bahwa nilai rata-rata indeks berada dinilai 102,62 dan tergolong tinggi hal ini menunjukan bahwa komitmen organisasi antar pegawai SKPD di Kabupaten Brebes kuat. Nilai indeks minimum variabel komitmen organisasi berada dinilai 98,75 yang tergolong masih tinggi dan skor maksimum 107,25. Kualitas laporan keuangan Pemerintah Daerah dengan hasil nilai rata-rata indeks 105,84 yang tergolong kategori tinggi berarti laporan keuangan yang disusun oleh SKPD Kabupaten Brebes rata-rata telah baik

\section{Hasil Pengujian Model Pengukuran (Outer Model)}

\section{Gambar 1 Hasil Outer Model}

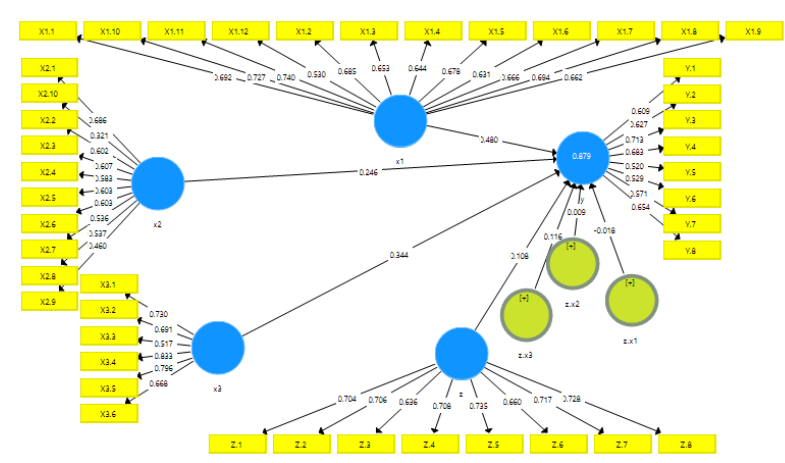

Sumber : Hasil olah data primer, 2020

Pengujian outer model bertujuan untuk menilai validitas dan reliabilitas model. Dalam menguji validitas suatu data dievaluasi melalui validitas convergent dan validitas discriminant dari indikator pembentuk konstruk laten. Validitas convergent berhubungan dengan prinsip bahwa indikator sebagai pengukur dari suatu konstruk seharusnya berkorelasi 
tinggi yang dapat dilihat dari loading factor dan average variance extracted (AVE). Validitas discriminant berhubungan dengan prinsip bahwa pengukur konstruk yang berbeda seharusnya tidak berkorelasi dengan tinggi, selanjutnya dilakukan uji reliabilitas yang dilakukan untuk membuktikan akurasi, konsistensi dan ketepatan instrumen dalam mengukur konstruk (Ghozali \& Latan, 2015).

Uji validitas

a. Average Variance Extracted (AVE)

Tabel 1

Hasil Average Variance Extracted (AVE)

\begin{tabular}{|l|c|}
\hline Variabel & $\begin{array}{c}\text { Average } \\
\text { Variance } \\
\text { Extracted } \\
\text { (AVE) }\end{array}$ \\
\hline $\begin{array}{l}\text { Penerapan Standar Akuntansi } \\
\text { Pemerintah }\end{array}$ & 0.504 \\
\hline Sistem Pengendalian Inter & 0.531 \\
\hline $\begin{array}{l}\text { Pemanfaatan Teknologi } \\
\text { Informasi }\end{array}$ & 0.507 \\
\hline $\begin{array}{l}\text { Komitmen Organisasi } \\
\text { Kualitas Laporan Keuangan } \\
\text { Pemerintah Daerah }\end{array}$ & 0.520 \\
\hline $\begin{array}{l}\text { Komitmen Organisasi dengan } \\
\text { Penerapan Standar Akuntansi }\end{array}$ & 1.000 \\
\hline $\begin{array}{l}\text { Komitmen Organisasi dengan } \\
\text { Sistem Pengendalian Intern }\end{array}$ & 1.000 \\
\hline $\begin{array}{l}\text { Komitmen Organisasi dengan } \\
\text { Pemanfaatan Teknologi } \\
\text { Informasi }\end{array}$ & 1.000 \\
\hline
\end{tabular}
2020

Uji Validitas dapat dilihat dari nilai AVE dengan nilai pembatasan yaitu 0,5 . Berdasarkan tabel diatas diketahui bahwa semua variabel memiliki nilai $\mathrm{AVE}>0,5$, sehingga dapat diartikan bahwa setiap variabel memenuhi syarat kriteria AVE.

\section{b. Loading Factor / outer loading}

Suatu indikator dinyatakan memenuhi covergent validity dalam kategori baik apabila nilai outer loading>
0,7 , namun untuk penelitian tahap awal dari pengembangan skala pengukuran, nilai loading faktor $0,5-0,6$ masih dianggap cukup (Ghozali \& Latan, 2015).

c. Cross Loading

Uji validitas discriminant indikator reflektif dapat diketahui melalui hasil cross loading antara indikator dengan konstruknya. Nilai korelasi konstruk dengan indikatornya lebih tinggi dibanding dengan korelasi indikator anatomi dengan konstruk lainnya. Hal itu menunjukan bahwa tiap blok variabel lebih baik dibanding dengan indikator pada tiap blok lainnya, sehingga validitas discriminant pada data tersebut terpenuhi.

\subsubsection{Uji Reliabilitas}

a. Cronbach's Alpha

Tabel 2

Hasil Cronbach's Alpha

\begin{tabular}{|c|c|}
\hline Variabel & $\begin{array}{l}\text { Cronbach's } \\
\text { Alpha }\end{array}$ \\
\hline Penerapan & r0.859 \\
\hline Akuntansi Pemerintah & \\
\hline Sistem Pengendalian Inter & 0.711 \\
\hline $\begin{array}{l}\text { Pemanfaatan } \\
\text { Informasi }\end{array}$ & i 0.803 \\
\hline Komitmen Organisasi & 0.847 \\
\hline $\begin{array}{l}\text { Kualitas Laporan Keuangan } \\
\text { Pemerintah Daerah }\end{array}$ & 0.710 \\
\hline $\begin{array}{l}\text { Komitmen Organisasi } \\
\text { dengan Penerapan Standar } \\
\text { Akuntansi }\end{array}$ & 1.000 \\
\hline $\begin{array}{lr}\text { Komitmen } & \text { Organisasi } \\
\text { dengan } & \text { Sistem } \\
\text { Pengendalian Intern }\end{array}$ & 1.000 \\
\hline \begin{tabular}{|lr} 
Komitmen & Organisasi \\
dengan & Pemanfaatan \\
Teknologi & Informasi
\end{tabular} & 1.000 \\
\hline
\end{tabular}

Berdasarkan data tersebut diketahui bahwa nilai cronbach's alpha pada setiap variabel telah terpenuhi dengan nilai pembatas $>0,7$. sehingga 
dapat disimpulkan untuk setiap variabel telah memenuhi syarat nilai cronbach's alpha yang artinya variabel tersebut reliabel.

\section{Composite Reliability}

Tabel 3

Hasil Composite Reliability

\begin{tabular}{|l|l|}
\hline Variabel & Composite Reliability \\
\hline $\begin{array}{l}\text { Penerapan Standar Akuntansi } \\
\text { Pemerintah }\end{array}$ & 0.890 \\
\hline Sistem Pengendalian Inter & 0.819 \\
\hline Pemanfaatan Teknologi Informasi & 0.857 \\
\hline \begin{tabular}{l} 
Komitmen Organisasi \\
\hline $\begin{array}{l}\text { Kualitas Laporan Keuangan } \\
\text { Pemerintah Daerah }\end{array}$
\end{tabular} & 0.883 \\
\hline $\begin{array}{l}\text { Komitmen Organisasi dengan } \\
\text { Penerapan Standar Akuntansi }\end{array}$ & 1.000 \\
\hline $\begin{array}{l}\text { Komitmen Organisasi dengan } \\
\text { Sistem Pengendalian Intern }\end{array}$ & 1.000 \\
\hline $\begin{array}{l}\text { Komitmen Organisasi dengan } \\
\text { Pemanfaatan Teknologi Informasi }\end{array}$ & \\
\hline
\end{tabular}

Sumber : Hasil olah data primer, 2020

Berdasarkan hasil tersebut, nilai composite reliability pada semua variabel memiliki nilai $>0,7$ yang artinya setiap variabel dalam penelitian ini sudah memenuhi syarat dan dapat dikatakan andal atau reliabel

\section{Gambar 2}

\section{Hasil Outer Model Setelah direduksi}

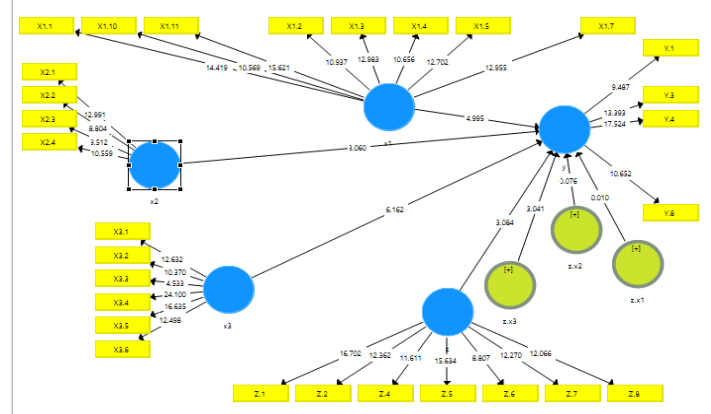

Hasil Pengujian Model Struktural (Inner Model)

Pengujian inner model dilakukan menggunakan prosedur bootstrapping yang merupakan analisa dengan tujuan untuk melihat besarnya persentase variance yang dijelaskan dengan melihat nilai $R$-Square untuk konstruk
endogen.Selain nilai $R$-Square pengujian inner model juga digunakan untuk mengetahui pengaruh antara variabel eksogen dengan variabel endogen dilihat dari hasil uji signifikansi. Berikut hasil olah data pengujian inner model menggunakan prosedur bootstrapping :

\subsubsection{R-Square}

Nilai $R$-Square sebesar 0,711, yang artinya variabel kualitas laporan keuangan Pemerintah Daerah (variabel dependen) dapat dijelaskan $71 \%$ dari penelitian ini dan $29 \%$ lainnya dipengaruhi oleh variabel lain diluar dari penelitian ini.

\subsubsection{Uji Signifikansi (Uji Hipotesis) \\ Hasil uji dapat dikatakan} berpengaruh apabila nilai $p$-value $<0,05$ dan t-statistik $>1,96$, selanjutnya untuk mengetahui arah pengaruh variabel independen dengan variabel dependen dapat diketahui dari nilai original sampel masing-masing uji pengaruh. Hasil nilai original sampel bertanda positif maka arah pengaruh variabel independen terhadap variabel dependen adalah positif/searah, sedangkan jika nilai original sampel bertanda negatif maka arah hubungan pengaruh variabel independen terhadap variabel dependen adalah berlawanan. Uji signifikansi dilakukan melalui proses bootstrapping. Hasil nilai signifikansi dapat diketahui melalui output path coefficient.

Tabel 4

Hasil Path Coeficients

\begin{tabular}{|c|c|c|c|}
\hline & $\begin{array}{l}\text { Original } \\
\text { sampel } \\
(\mathrm{O})\end{array}$ & $\begin{array}{l}\text { T } \\
\text { Statistic }\end{array}$ & cValues \\
\hline $\begin{array}{l}\text { Penerapan Standar } \\
\text { Akuntansi } \\
\text { Pemerintah } \\
\text { berpengaruh positif } \\
\text { terhadap Kualitas } \\
\text { Laporan Keuangan } \\
\text { Pemerintah Daerah }\end{array}$ & f0.384 & 4.995 & 0.000 \\
\hline $\begin{array}{l}\text { Sistem } \\
\text { Pengendalian Inte }\end{array}$ & 94 & 3.060 & 0.001 \\
\hline
\end{tabular}




\begin{tabular}{|c|c|c|c|}
\hline $\begin{array}{lr}\text { berpengaruh } & \text { positif } \\
\text { terhadap } & \text { Kualitas } \\
\text { Laporan } & \text { Keuangan } \\
\text { Pemerintah Daerah }\end{array}$ & & & \\
\hline \begin{tabular}{|l|} 
Pemanfaatan \\
Teknologi \\
berpengaruh positif \\
terhadap $\quad$ Kualitas \\
Laporan Keuangan \\
Pemerintah Daerah
\end{tabular} & 0.364 & 6.162 & 0.000 \\
\hline $\begin{array}{|ll|}\text { Komitmen } & \\
\text { Organisasi } & \text { mampu } \\
\text { memperkuat } & \\
\text { pengaruh } & \\
\text { Penerapan } & \text { Standar } \\
\text { Akuntansi } & \text { terhadap } \\
\text { Kualitas } & \text { Laporan } \\
\text { Keuangan } & \\
\text { Pemerintah } & \text { Daerah } \\
\end{array}$ & -0.001 & 0.010 & 0.496 \\
\hline $\begin{array}{|lr|}\text { Komitmen } & \\
\text { Organisasi } & \text { mampu } \\
\text { memperkuat } & \\
\text { pengaruh rran } & \text { Sistem } \\
\text { Pengendalian } & \text { Intern } \\
\text { terhadap } & \text { Kualitas } \\
\text { Laporan } & \text { Keuangan } \\
\text { Pemerintah } & \text { Daerah }\end{array}$ & -0.004 & 0.076 & 0.470 \\
\hline \begin{tabular}{|l|} 
Komitmen \\
Organisasi mampu \\
memperkuat \\
pengaruh \\
Pemanfaatan \\
Teknologi Informasi \\
terhadap Kualitas \\
Laporan Keuangan \\
Pemerintah Daerah
\end{tabular} & 0.158 & 3.041 & 0.001 \\
\hline
\end{tabular}

Sumber : Hasil olah data primer, 2020

\section{Pembahasan}

Hipotesis 1 : Penerapan standar akuntansi pemerintah berpengaruh positif terhadap kualitas laporan keuangan Pemerintah Daerah

Hasil uji signifikansi menunjukkan bahwa penerapan standar akuntansi pemerintah berpengaruh positif terhadap kualitas laporan keuangan Pemerintah
Daerah. Penerapan standar akuntansi pemerintah yang semakin baik akan menghasilkan laporan keuangan yang berkualitas. Sesuai dengan teori signaling pemerintah akan memberikan informasi berupa laporan keuangan yang berkualitas sebagai bentuk tanggung jawab pemerintah atas sumber daya yang telah dipercayakan kepada pemerintah. Penerapan standar akuntansi pemerintah di SKPD Kabupaten Brebes telah adanya perbaikan sehingga akan mempengaruhi penyusunan laporan keuangan. Penelitian ini sejalan dengan Sanjaya \& Haryani, (2016) dan Sari \& Fadli, (2019) yang menyatakan bahwa penerapan standar akuntansi pemerintah berpengaruh positif terhadap kualitas laporan keuangan Pemerintah Daerah.

Hipotesis 2 : Penerapan sistem pengendalian intern berpengaruh positif terhadap kualitas laporan keuangan Pemerintah Daerah

Hasil pengujian signifikansi menunjukkan variabel sistem pengendalian intern berpengaruh positif terhadap kualitas laporan keuangan Pemerintah Daerah.Penerapan Sistem pengendalian intern seperti lingkuan pengendalian, penilain resiko, informasi dan komunikasi aktivitas pengendalian dan kegiatan pemantauan secara umum telah dilaksanakan dengan baik oleh pimpinan dan pegawai dalam mencapai tujuan organisai di SKPD Kabupaten Brebes. Artinya dalam suatu SKPD apabila sistem pengendalian intern yang dilakukan oleh pimpinan atau pegawai diterapkan dengan baik dan sesuai prosedur maka akan tercipta laporan keuangan yang berkualitas. Pernyataan ini sesuai dengan penelitian Andrianto \& Rahmawati, (2017) dan Siwambudi et al. (2017) yang menyatakan bahwa sistem pengendalian intern berpengaruh positif terhadap kualitas laporan keuangan. 
Hipotesis 3 : Pemanfaatan Teknologi Informasi berpengaruh positif terhadap kualitas laporan keuangan Pemerintah Daerah

Hasil uji signifikansi menunjukan bahwavariabel pemanfaatan teknologi informasi terhadap variabel kualitas laporan keuangan Pemerintah Daerah berpengaruh positif yang artinya bahwa $\mathrm{H}_{3}$ diterima.Berdasarkan pengamatan hasil pengisian kuesioner bahwa teknologi informasi pada SKPD di Kabupaten Brebes telah dimanfaatkan dengan baik seperti penggunaan komputer, jaringan internet / jaringan lokal dan penggunaan software yang sesuai dengan peraturan, dengan memanfaatkan teknologi informasi, hasil laporan keuangan lebih akurat dibanding menggunakan manual sehingga laporan keuangan yang disajikan menjadi lebih tepat waktu dan andal. keuangan Hasil penelitian ini sejalan dengan Andrianto \& Rahmawati (2017) dan Adrian et al. (2019) yang menyatakan bahwa pemanfaatan teknologi informasi berpengaruh pada kualitas laporan keuangan Pemerintah Daerah.

Hipotesis 4 : Komitmen organisasi memperkuat pengaruh penerapan standar akuntansi pemerintah terhadap kualitas laporan keuangan Pemerintah Daerah

Hasil pengujian signifikansi menunjukkan bahwa komitmen organisasi tidak mampu memoderasi pengaruh penerapan standar akuntansi pemerintah terhadap kualitas laporan keuangan Pemerintah Daerah. Hasil $\mathrm{H}_{1}$ membuktikan bahwa penerapan standar akuntansi pemerintah berpengaruh positif terhadap kualitas laporan keuangan, namun setelah dimoderasi oleh komitmen organisasi tidak menunjukan adanya pengaruh komitmen organisasi terhadap variabel penerapan standar akuntansi terhadap variabel kualitas laporan keuangan, hal ini disebabkan karena penerapan standar akuntansi pemerintah telah dilaksanakan dengan baik sehingga adanya komitmen organisasi maupun tidak akan menghasilkan laporan keuangan yang berkualitas. Penelitian ini konsisten dengan Adrian et al. (2019) yang menyatakan komitmen organisasi tidak mampu memoderasi pengaruh penerapan standar akuntansi pemerintah terhadap kualitas laporan keuangan.

Hipotesis 5 : Komitmen organisasi memperkuat pengaruh sistem pengendalian intern terhadap kualitas laporan keuangan Pemerintah Daerah.

Hasil pengujian hipotesis variabel moderasi komitmen organisasi dengan pengaruh sistem pengendalian intern terhadap kualitas laporan keuangan ditolak.Hal ini menandakan bahwa komitmen organisasi tidak dapat memoderasi pengaruh sistem pengendalian intern terhadap kualitas laporan keuangan. Secara teori komitmen organisasi mampu mempengaruhi kinerja dan tindakan pegawai, pegawai yang berkomitmen tinggi akan memaksimalkan kinerja sehingga hasil pekerjaan akan baik, namun pada penelitian yang dilakukan di SKPD Kabupaten Brebes hal tersebut tidak terjadi dikarenakan pengendalian intern merupakan sistem keseluruhan yang menjadi satu tidak dapat dipisahkan dalam suatu organisasi, pengendalian intern merupakan proses yang menyatu dengan kegiatan operasional organisasi, serta menjadi dasar pelaksanaan kegiatan yang dilakukan terus menerus, sehingga komitmen organisasi tidak mampu memoderasi pengaruh sistem pengendalian intern terhadap kualitas laporan keuangan. Penelitian ini sejalan dengan Siwambudi et al. (2017) dan Andrianto \& Rahmawati (2017) yang menyatakan komitmen organisasi tidak mampu memoderasi pengaruh sistem 
pengendalian intern terhadap kualitas laporan keuangan Pemerintah Daerah.

Hipotesis 6 : Komitmen organisasi memperkuat pengaruh pemanfaatan teknologi informasi terhadap kualitas laporan keuangan Pemerintah Daerah.

Hasil uji signifikansi menunjukkan komitmen organisasi mampu memperkuat pengaruh pemanfaatan teknologi informasi terhadap kualitas laporan keuangan Pemerintah Daerah. Hal ini menunjukan bahwa pegawai yang memiliki komitmen tinggi akan melaksanakan tugas secara maksimal dengan memanfaatkan teknologi informasi yang ada di SKPD Kabupaten Brebes. Penelitian ini sejalan dengan Alminda \& Marfuah (2018) yang menyatakan komitmen organisasi memperkuat pengaruh pemanfaatan teknologi informasi terhadap variabel kualitas laporan keuangan Pemerintah Daerah.

\section{KESIMPULAN}

Hasil penelitian yang dilakukan di SKPD Kabupaten Brebes dapat disimpulkan bahwa :

1. Penerapan standar akuntansi pemerintah, sistem pengendalian intern dan pemanfaatan teknologi informasi berpengaruh positif terhadap kualitas laporan keuangan Pemerintah Daerah.

2. Komitmen organisasi tidak mampu memoderasi pengaruh penerapan standar akuntansi pemerintah dan sistem pengendalian intern terhadap kaulitas laporan keuangan Pemerintah Daerah.

3. Komitmen organisasi mampu memperkuat pengaruh pemanfaatan teknologi informasi terhadap kualitas laporan keuangan Pemerintah Daerah.

\section{REFERENCES}

Adrian, R., Erlina, Yeni Absah (2019). Analysis Of Factors Affecting The Quality Of Financial Statements Regency AAFTApparatus Work Unit In The Government Of Aceh Tamiang Regency With
Organizational Commitments As Moderating Variables. Universitas Sumatra Utara.

Alminda, P., \& Marfuah, (2018). Peran Komitmen Organisasi Dalam Memoderasi Pengaruh Kompetensi Sumberdaya Manusia, Sistem Pengendalian Intern Dan Pemanfaatan Teknologi Informasi Terhadap Kualitas Laporan Keuangan Pemerintah Daerah. Jurnal Analisi Bisnis Ekonomi.

American Institute of Certifield Public Accountants, (2014). The Importance Of Internal Control In Financial Reporting And Safeguarding Plan Assets.American Institute of CPAs. European.

Andrianto, E., \& Diana Rahmawati, S.E., M. S. (2017). Pengaruh Kapasitas Sumber Daya Manusia, Pemanfaatan Teknologi Informasi, Dan Sistem Pengendalian Internal Pemerintah Terhadap Kualitas Laporan Keuangan Daerah Dengan Komitmen Organisasi Sebagai Variabel Moderasi (Studi Empiris Pada Satuan Kerja Perangkat Daerah di Kabupaten Sleman) . Universitas Negeri Yogyakarta, 1-19.

Armel, R., Nasir, A., \& Safitri, D. (2017). Pengaruh Kompetensi Sumber Daya Manusia, Penerapan Standar Akuntansi Pemerintahan, Pemanfaatan Teknologi Informasi dan Sistem Pengendalian Internal terhadap Kualitas Laporan Keuangan Pemerintah Daerah (Studi pada Satuan Kerja Perangkat Daerah Kota Dumai). Jurnal Online Mahasiswa Fakultas Ekonomi Universitas Riau, 4(1), 105-119.

Ghozali, Imam Dan Latan, Hengky. (2015). Partial Least Square Konsep Teknik Dan Aplikasi Menggunakan Program SmartPLS 3.0 (2nd Edition). Semarang: Badan Penerbit Universitas Diponegoro

Mahmudi. 2016. Analisis Laporan keuangan Pemerintah Daerah. Yogyakarta: UPP STIM YKPN

Meyer, J. P., Allen, N. J. 1991. A ThreeComponent Conceptualization of Organizational Commitment. Human 
Resource Management Review, Vol.1, pp.61-89.

Mokoginta, N., Lambey, L., \& Pontoh, W. (2017). Pengaruh Sistem Pengendalian Intern Dan Prinsip Pengelolaan Keuangan Daerah Terhadap Kualitas Laporan Keuangan Pada Pemerintah Daerah Kabupaten Bolaang Mongondow Selatan. Jurnal Riset Akuntansi Going Concern, 12(2), 874-890.

Nadir, R., \& Hasyim, H. (2017). Pengaruh Pemanfaatan Teknologi Informasi, Kompetensi Sumber Daya Manusia, Terhadap Kualitas Laporan Keuangan Pemerintah Daerah Dengan Variabel Intervening Standar Akuntansi Pemerintah Berbasis Akrual (Studi Empiris Di Pemda Kabupaten Barru). Akuntabel, 14(1), 57.

Pangestu et al.(2019). Pengaruh Kualitas Sumber Daya Manusia, Sistem Pengendalian Intern, Dan Pemanfaatan Teknologi Informasi Terhadap Kualitas Laporan Keuangan Di Satuan Kerja Perangkat Daerah (SKPD) Kabupaten Ponorogo. Jurnal Ekonomi Manajemen Akuntansi. vol. 3 Republik Indonesia, Peraturan Pemerintah No 56 Tahun 2005 Tentang Sistem informasi keuangan daerah.

Republik Indonesia, Peraturan Pemerintah No. 60 Tahun 2008 Tentang Sistem Pengendalian intern Pemerintah.

Republik Indonesia, Peraturan Pemerintah No 71 Tahun 2010 Tentang Standar Akuntansi Pemerintahan.

Republik Indonesia, Peraturan Pemerintah

No. 17 Tahun 2003 Tentang Keuangan Negara.

Republik Indonesia, Peraturan Pemerintah No. 1 Tahun 2004 Tentang Perbendaharaan Negara

Sanjaya, A., \& Haryani, E. (2016). Pengaruh Penerapan Standar Akuntansi Pemerintahan, Sistem Pengendalian Intern, Sistem Akuntansi Keuangan Daerah, Dan Sumber Daya Manusia Terhadap Kualitas Laporan Keuangan Pemerintah Daerah Dengan
Komitmen Organisasi Sebagai

Pemoderasi. Jurnal Online

Mahasiswa Fakultas Ekonomi Universitas Riau, 4(1), 366-380.

Sari, G. I., \& Fadli, F. (2019). Analisis Faktor-Faktor Yang Mempengaruhi Kualitas Laporan Keuangan Daerah. Jurnal Akuntansi, 7(3), 17-34.

Setyaningrum, W. \& Atiningsih, S.,(2019)Pengaruh Penerapan Sistem Akuntansi Keuangan Daerah, Kompetensi Sumber Daya Manusia Dan Sistem Pengendalian Intern Terhadap Kualitas Laporan Keuangan Pemerintah Daerah Dengan Komitmen Organisasi Sebagai Variabel Moderasi Di Kota Salatiga. 738-748.

Setyowati, L., Isthika, W., \& Pratiwi, R. D. (2016). Faktor-Faktor Yang Mempengaruhi Kualitas Laporan Keuangan Pemerintah Daerah Kota Semarang.20(2), 179.

Sholohah, S. A., \& Sulistyawati, A. I. (2018).Kualitas Laporan Keuangan dan faktor-Faktor Yang Mempengaruhinya (Studi Kasus Pada DPKAD Kota Semarang)Fokus Ekonomi. Jurnal Fokus Ekonomi, 13(2), 280-300.

Siwambudi, I. G. N., Yasa, G. W., \& Badera, I. D. N. (2017). Kompetensi Sdm Dan Sistem Pengendalian Intern Pada Kualitas Laporan Keuangan Fakultas Ekonomi Dan Bisnis Universitas Udayana (Unud), Bali. EJurnal Ekonomi Dan Bisnis Universitas Udayana, 1, 385-416.

Suwanda, D., (2015). Factors Affecting Quality Of Local Government Financial Statements To Get Unqualified Opinion (WTP) Of Audit Board Ofthe Republic Of Indonesia (BPK). Research Journal Of Finance And Accounting

Spence, Michael. 1973. Job Market Signaling. The Quarterly Journal Of Economics, Vol. 87, No. 3. (Aug., 1973)

Wiley, John \& Sons, Inc., (2017) Metode Penelitian Untuk Bisnis Edisi 6 Buku 2. Jakarta. Salemba Empat 